\title{
The history of the Revolution and Civil War in Kamchatka in the archival funds of the Kamchatka Krai State Archive: a source-study review
}

\author{
Natalya Kamardina ${ }^{1,}$, Valentina Ilina $^{1}$ \\ ${ }^{1}$ Vitus Bering Kamchatka State University, 683032, 4 Pogranichnaya str., Petropavlovsk- \\ Kamchatsky, Russia
}

\begin{abstract}
This article is devoted to the problems of collection and classification of the historical sources regarding the history of the Great Russian Revolution of 1917. The authors concentrated on the opportunities of using different sources kept at the archives of the Far East (Vladivostok, Khabarovsk, Petropavlovsk-Kamchatskiy) in order to comprehensively review the events which took place in Kamchatka in 1917-1922. The idea of considering a written historical source as a subjectified reflection of the past, which is the only bearer of the historical truth, lays the foundation for analyzing the source-study basis of the problem. The given research helps to outline general directions of work aimed at studying the history of the Kamchatka krai shortly before the Revolution and in the years of the Revolution and Civil War and also to determine further development of the designated issues.
\end{abstract}

\section{Introduction}

The origins and meaning of the Russian Revolution have been extensively debated for a hundred years already. Thousands of pages of scientific works and pieces of social and political journalism created in different years are devoted to this event. However, it is still a topical theme. The range of existing opinions, conceptions, and approaches concerning different issues is quite diverse and requires critical rethinking. The most important accomplishment of the academic community in this field is the development of some basic points of the 1917 Revolution conception by the Scientific Council "The history of revolutions in Russia" of the Russian History Institute of the Russian Academy of Sciences and also by the Institute of History, Archeology, and Ethnography of the Peoples of the Far East FEB RAS [25].

Over the last decades, a lot of scientific works devoted to the events of the Revolution, the Civil War, and intervention in the Far East have been created on the basis of new approaches. However, due to some objective reasons, no complex work which would present a general overview of the Kamchatka krai development in the years of

* Corresponding author: nata_kamardina@mail.ru 
revolutionary reforms and Civil War has appeared yet. This gap is to be filled, and the most important stage of such activity should involve revealing a set of representative historical sources. With the help of modern methodological approaches and identified sets of documents researchers will be able to present the overview of the events which took place in Kamchatka in 1917 more objectively and in many aspects.

\section{Research methodology}

It is well-known that the eople's historical mind is formed not only on the basis of "correct" scientific and educational literature but also under the influence of the established myths and misconceptions acquired in various sources, which can often be unreliable. The distorted interpretation of the past events is facilitated by both the current political situation and the inability of extracting information from original sources, as well as readiness to take on faith somebody's conclusions. It is unacceptable for the scientist to treat the historical reality in such a way. Materialistic comprehension of history recognizes the properties of the historical reality as unlimited but invariant, since the facts of reality are constant across time and space, and in this sense they are objective in regard to the participants of the events as well as to the historians examining them. Reflected in the historical source, the fact loses its objectivity, being reproduced by the author of the source. Such a reflection is unambiguous; though, it is infinite from the point of view of the internal essence, as the objective reality is unlimited. The historian reconstructs reality on the basis of facts gained from the source and, thus, creates a scientific and historical fact. As a result, the scientific and historical fact turns to be a double subjectified reflection of the past. Actually, the obtained historical knowledge essentially cannot be of an invariant character, it is incomplete, changeable, and infinite in its content. Scientists face the task of search and apprehension of the epoch's various pieces of evidence. Carrying out their investigations, they turn to historical sources stored in archives which contain primary data about people, society, state in different periods. Thus, critical work with the sources, which are the only bearers of historical truth, becomes of special value.

In 2014-2016, a considerable array of sources necessary for the investigation of the designated problem was revealed in the three archives of the Russian Federation: the Kamchatka Krai State Archive (KKSA), the Khabarovsk Krai State Archive (KhKSA), and the Russian Historical Archive of the Far East (RSHA FE). In the course of further work, the documents were processed and systemized.

\section{Results}

There are more than twenty archival funds in the State Archive of Kamchatka krai, in which documents on one of the most complicated and ambiguous periods of the newest regional history are kept. According to the sources, one could find a lot of problems and contradictions in the situation which occurred in the region shortly before the Revolution and in its economic exploitation. But it is hardly possible to insist on the presence of confirmed preconditions of the Revolution on these remote outskirts. The documents of Kamchatka Krai State Archive allow us to see the dissimilarities in the events in the centre and on the periphery. Involving Kamchatka's residents into the revolutionary process, the shift of the public mood towards left-wing politics have been determined since the summer of 1917 by the influx of people from the "mainland" and the arrival of military forces in which pro-Bolshevik moods were especially intense. In this respect, the Fund R-8 "Petropavlovsk City Duma" [3] and the Fund R-80 "The 3d Kamchtka regional convention of population representatives, the city of Petropavlovsk-na-Kamchatke" (1920) [5] are of 
great importance. The data of these archival funds contain the lists of participants, reports on the current situation, suggestions concerning the development of the region, resolutions on the issues under discussion. The $3 \mathrm{~d}$ convention is especially significant in regard to the decisions taken. In the course of its proceedings, one could clearly observe the readiness for cooperation on the part of all political forces of Kamchatka aimed at the recovery of the normal life in the peninsula.

The situation which occurred in the local settlements should be studied through the archival funds of volost (district) and village committees of the Petropavlovskiy uyezd (county) (1918-1922). These are the following archival funds: R-86 [6], R-99 [7], R-126 [8], R-201 [10], R-203 [11], R-224 [12], R-240 [14], R-249 [15]. Studying the minutes of general assemblies and public meetings of the citizens, we can trace the change in people's attitude towards the current political events in the region and in the country.

Kamchatka residents, as well as other residents of the Far East, supported the February Revolution, expressing disapproval of the Bolsheviks' demonstration in Petrograd on the 34 of July, 1917. However, the October uprising, the work of the 2nd All-Russian Congress of Soviets did not convince a significant majority of the Far-Easterners that opting for socialism was inevitable, and it is confirmed by the comparatively late acceptance of the Council of People's Commissars and the results of elections to the Constituent Assembly.

The archival fund R-497 [16] represented by personal documents of I. Ye. Larin, the first chairman of Petropavlovsk city and Kamchatka regional Soviet of Peasants', Workers' and Soldiers' Deputies, is also of great importance for the reconstruction of the revolutionary events in Kamchatka. In addition to the memoirs of I. Ye. Larin and participants of the revolutionary events of 1917-1925, the personal fund contains copies of documents, which are kept in the central archives of the Russian Federation. Also, there is collection of documents No P-555 titled "Documents on the participants of the struggle aimed at the establishment of the Soviet power in Kamchatka" in the archive. The given fund was founded in 1967 in connection with the appearance of material and data in the archive provided by former participants of the struggle aimed at the establishment of the Soviet power in Kamchatka and their relatives. The collection contains more than 300 documents. They mostly include documents of biographical character - questionnaires, reference letters, personal records, and credentials of the participants, among which are the following figures: A. S. Lukashevskiy, A. S. Toporkov-Oleynik, P. G. Ivashkin, M. I. Savchenko-Slavskiyб and others. Certainly, documents of personal origin are a very specific source, because they estimate the event and the author's participation in it from the subjective point of view. The authenticity of the memories written down fifty years later than the described events took place must be checked against the archival documents as well as by means of comparison with the memories of other participants of the revolutionary events.

In addition, the archival funds of the Kamchatka Krai State Archive gathered material on the activity of local organs of revolutionary power in Kamchatka for the period of 1917 1922. Together with the sitting minutes of regional and city organizations, which functioned in Kamchatka during the Revolution and Civil War, there are reports, certificates, annexes involving various aspects of economic, ideological and propaganda activity among the residents of the Kamchatka region. This information enables us to reconsider the events and to look at the specificity of the Soviet power establishment in the region from a new angle.

For the reconstruction of the public mood atmosphere, the sources of personal origin are first to be applied. But we have not yet found any letters and diaries, which belonged to Petropavlovsk residents - contemporaries of the revolutions - and which were written immediately after the events, in the archives. Therefore, researchers can use the material of periodicals as the main source for their investigation. The local newspaper "Kamchatskiy 
Listok" (Kamchatka's Leaflet) [28] is a unique source, because it is the first printed newspaper of Kamchatka. It was edited from the spring of 1914 (May 2, 1914) till the spring of 1918. The majority of the issues are of 1917 (except the issues of April, May, and June in 1917). This specific historical source presents a collective diary of the city life, very detailed, fixing everything that was happening day after day. The newspaper information is quite representative. In provincial cities, where there were no events of great national significance, newspapers focused thoroughly on big and small highlights of the local scale in order to attract the attention of the reader. Besides, by 1917 the former censorship had been eliminated, and a new censorship system which was gradually established after Bolsheviks came to power had not appeared yet. Mostly, the information published in the newspaper can be considered as correct. During the period of the power change, "the White" (Tsarists) and "the Red" (Bolsheviks, Communists) made attempts to organize the issue of their own newspapers. The following kinds of periodicals were preserved in the archive (although not to the fullest extent): "Kamchatskiy Vestnik" (Kamchatka Reporter), "Izvestiya Soveta rabochikh i soldatskikh deputatov gor. Petropavlovsk"» (News-Bulletin of Petropavlovsk Soviet of Workers' and Soldiers' Deputies), "Kamchatskiye Izvestiya" (Kamchatka News-Bulletin), "Izvestiya Kamchatskogo Oblasnogo trudovogo naroda" (News-Bulletin of Kamchatka Region's working people), "Izvestiya gubrevkoma” (NewsBulletin of Gubernial Revolutionary Committee), and others. The analysis of the newspaper material makes it possible to trace changes in the political behaviour of the residents of a small city in the post-February and post-October arena, to reveal the reasons and circumstances which determined these changes.

The State Archive of the Khabarovsk krai also keeps material on the history of the Revolution in Kamchatka. Records of Dalistpart (the Far-Eastern Commission on the History of the Revolution and $\mathrm{RKPb}$ ) are of special interest. The documentary material gathered immediately after the events are presented in the archival fund of Dalistpart in the State Archive of the Khabarovsk krai [17, 1359 units] which was a constituent part of a large system of Istparts. The funds of the Party Archive of the RSFSR Communist Party Khabarovsky kraikom /regional committee/ (Fund P-442) [18] and of the Agency on Archival Affairs of the Khabarovsk krai administration (Fund R-39) [20] contain plans on collecting documents (annual plans and reports of the work performed) that allows us to highlight the cooperation of Dalistpart with the FER archival establishments and to estimate its role in the development of the archival service of the Far East. The materials of Fund P528 [19] reveal the role of Dalistpart in the foundation, development, and functioning of the Far-Eastern branch of the All-Russian Old Bolsheviks Society. The material of Funds R181 [21], R-663 [22], R-1277 [23] shows the interaction of Dalistpart and commissions on the affairs of former Red Guards members and guerillas affiliated with the Executive Committees of the Far East Councils of various levels [the activity of Dalistpart is considered in detail in 47].

Various sources of information on the history of Kamchatka in the period of 1917-1922 are presented in the Fund of Dalistpart of the Khabarovsk krai State Archive. Many of them are official documents: resolutions, memoranda, minutes of various state and party organs related to the organization of life in the Kamchatka peninsula. But, first of all, a researcher is interested in sources of personal origin. According to the existing classification, these are mainly the sources of interpersonal communication with an indefinite addressee. The questionnaire developed by Dalistpart and sent out to all the party organizations of the country made it possible to systemize the sketchy data received from direct participants of the Revolution. It is these memories of the participants of the revolutionary events in Kamchatka that were originally laid in the basis of all historical overviews about the Revolution. For a modern researcher, it seems impossible to add anything new to what has been written by the predecessors. However, the modern reading of these historical sources 
allows us to look upon the events of the past in connection with new scientific knowledge. The following documents, for example, are of great interest: inquiry forms of the participants of the Revolution and Civil War in the Okhotsk region (F. Karayev, I. F. Burka, comrade Koryukin, V. Chekmarev, M.Monakhov [17, series 1, d. 408, pp.1-14]), the memories of N. Frolov, I. Yeliseyev [17, series 1, d. 406, pp. 1-9]. Manuscripts of nonpublished works of Dalistpart employees and assistance group members are kept in the archival fund. Their special value is determined by the fact that they enable us to analyze the degree of party-governmental censorship influence on the publishing activities of the Far-Eastern Istpart. Certainly, part of the material gathered at that time was published, but it was corrected quite a lot. The manuscripts of I. Larin's overview "the work of RKP(b) in Kamchatka" and comrade Massyuk's overview "The work conducted among the aboriginal women of Kamchatka" [17, series 1, d. 410, pp.2-40] (presented in the original variant) contain alterations, remarks, and corrections of the censors. The assessment review of $\mathrm{F}$. Slobodchikov's work [17, series 1, d. 111, pp. 20-76], written by a Dalistpart employee, was preserved: "The manuscript "October and Civil War in Kamchatka" is written on the basis of documentary material development, some participants' memories and the author's own memories. Comrade Slobodchikov is a member of All-Union Communist Party (bolsheviks), works in Kamchatka in the framework of the Control Commission of Workers' and Peasants' Inspection, is familiar with the historical situation and conditions of the Kamchatka region, which is a great advantage for any author of historical-revolutionary movement, but the lack of skills in scientific and research literary work and the shortage of sufficient theoretical background of the author has significantly influenced the quality of the manuscript. The drawbacks of the manuscript are quite correctable. On condition of thorough political editing and literary processing the booklet will be of great historical value" [17, series 1, d. 14, p. 17]. Also, notes on the content of I. Larin's work "The work of RKP(b) in Kamchatka" were preserved in the archival data: "The quality of this article is extremely poor. Both logic and stylistics are equally deficient. A lot of passages are written so badly that it is necessary to alter them entirely. Factual material also leaves much to be desired: the years are mixed up, ambivalent facts are present and so on. The exposition is haphazard and chaotic. It can be published only after a thorough fundamental rewriting. It would be better ... to replace this article with another one, well-grounded and linguistically correct. Must be rewritten" [17, series 1, d. 410, p. 1]. Thus, a modern researcher has an opportunity to make an analysis of the author's variants of the manuscript and, drawing upon the whole complex of sources, to subject the historical events to his or her own analysis and interpretation.

There is one more interesting source in the pieces of material sent by the Kamchatka party organization to Dalistpart. These are poems of the period of the October Revolution and Civil War in the Far East, created by direct participants of the revolutionary events in 1917 - 1929 [17, series 1, d. 199, pp. 180-186]. Though these poetic works are not of great artistic value, they give us a notion of feelings and emotions experienced by ordinary participants of the revolutionary events. A modern historian can consider these sources as in the reflection of the emotional state of the society in the years of the Revolution.

The collection of historical material was considered to be a matter of great importance, which is proved by the intercourse in correspondence between Dalistpart based in the Khabarovsk and Kamchatka Gubernial Committee. Thus, in the letter of October 4, 1931, comrade Tsypkin, acting for Head of Ispartotdel of the Far-Eastern Regional Committe of All-Union Communist Party (bolsheviks), says, "For the sufficient covering of the history of the October and Civil War in Kamchatka in the collections of works and other issues of Istpart it is necessary to send out urgently the archive of the Civil War... to arrange the collection of pieces of material and documents, memories and articles concerning the history of the October Revolution and Civil War in Kamchatka and the Kamchatka 
peninsula" [17, series 1, d. 408, pp.1-14]. In spite of the importance and large amount of the collected material and the preliminary work, Dalistpart never managed to publish documentary collections "The Far-Eastern organization of the All-Union Communist Party (bolsheviks) in the October Revolution and Civil War" and "Bolsheviks in the Civil War in the Far East" (they were prepared from 1935 till 1938, in the process of improvement were united in one collection of documents in three parts). The collection of documents "The Civil War in the Far East" shared the same fate (it was prepared from 1932 till 1938). Only in the late 1950-1960s, the collections were published [26].

Due to the established system of governing, the city of Vladivostok played a significant role in the life of Kamchatka. The main revolutionary events of 1917-1922 took place in this city and the main organs of power in the Far East were concentrated there. The data showing a connection of Kamchatka and Vladivostok are kept in the Russian State Archive of the Far East [46]. These are archival funds 1005 [39], R-1378 [40], [41], R-1382 [42], R1383 [43], R-1403 [45].

The 63 cases are presented in archival fund R-1378 [44]. For the reconstruction of revolutionary events it is important to consider the minutes of Kamchatka Regional Council's sittings concerning the organization of an inquiry commission for the investigation of the previous administration's power abuse according to the submitted applications; concerning the organization of food committee [40, series 1, d. 4]. Material of Kamchatka regional executive committee of the Provisional Government in the Far East, including the report of the commission on the convocation of the Second Kamchatka regional congress affiliated with Kamchatka Regional Council of Workers' and Peasants' deputies [40, series 1, d. 35]. The Fund R-1382 [42] contains 91 cases, including the case 30 , in which we can find proclamations of the military council of Ust-Kamchatsk volunteer detachment, Ust-Kamchatsk Volnarrekom (volost people's revolutionary committee) with an appeal to the residents of the Kamchatka-river delta calling them for the struggle with the armed bands of Birich, Bochkarev, Polyakov. The case 68 "Orders of the special agent of Priamurskoye government of 31 Dec, 1922, in the Okhotsko-Kamchatsky krai Birich Kh.P. and his correspondence with heads of training schools in Kamchatka region on the development of schooling in Kamchatka region" and the case 41 "Telephone correspondence with uyezd, volost, and village committees of Kamchatka region on the invocation of the 2nd extraordinary Petropavlovsk convention" are of great interest. The fund R-1383 [43] contains 18 cases. Among them are the case No 1 ("The minutes of Interim-Revolutionary Committee of the Kamchatka region on the election of the city commandant, on the order of activities in the regional administrative organs of Petropavlovsk etc."), the case No 4 ("The minutes of the Inquiry Commission of the Kamchatka Interim Military-Revolutionary Committee").

From the viewpoint of their type, diversity of the found data present official correspondence, minutes records of various commissions and committees sittings, as well as resolutions on the organization of various kinds of activity. The content of these documents allows us to see all the range of problems which were to be solved by different state organs and their representatives in the conditions of the remote North-Eastern periphery of Russia and to find out to what extent the new power decisions were executed.

Material of the personal character in the investigated archival funds of the Russian State Historical Archive of the Far East does not provide sufficient data. But for the reconstruction of complicated interrelationships of the revolutionary events participants in Kamchatka, it would be interesting to consider the case No 16 of the Archival fund R-1383 [43] on the illegal charge brought against the doctor Cheslav Kupriyanovich Shchipchinskiy, who was accused of sabotage and anti-Soviet activity, and his rehabilitation by the Second Kamchatka regional congress. The case materials contain personal letters, applications, resolutions concerning matters of revolutionary legitimacy of 
that period. This material shows how ambiguous the attitude of people towards the revolutionary events was, how their views changed, and what consequences it produced for them and their friends and relatives.

\section{Discussion of results}

The conducted analysis shows that the archival funds of state archives of the Far East contain representative material on the history of the Revolution and Civil War in Kamchatka. A large percentage of the given data has been already used by the Soviet researchers for studying the revolutionary events of 1917-1922. The published historical sources $[26,32,36,37]$ cannot be regarded as complete and objective as they were published during the period of party ideological dictate or during the years of perestroika when the methodological basis was not significantly changed.

The majority of investigations on the history of the Revolution and Civil War in the Far East were written in the 1950-80s. Thus, in the works of A. I. Krushanov [30, 31, 32], V. $\mathrm{V}$. Sonin [48], the main stages of the Revolution and Civil War in the remote periphery and their specificity were analyzed on the basis of a significant amount of material. A detailed analysis of the process of establishing the Soviet Power in Kamchatka is reflected in the investigations of B. I. Mukhachev [34, 35]. The variety of facts is rather great in these works, but the assessments are often influenced by politicization. The themes concerning the influence of the February Revolution on Kamchatka's political and social life, the process of the sovietization of its territory, Kamchatka's being a part of the Far-Eastern Republic, Kamchatka between "the White" and "the Red," leaders of political forces and other very important issues have not been sufficiently explored.

Since the 1990s, we have observed a qualitatively new period in studying the problem of the Revolution, the Civil War, and intervention in the Far East. In contrast with the majority of the Soviet period works, the events of 1917-1922 in the Far East are presented not through the lens of heroics of the Revolution and Civil War, but as a great tragedy of the whole people. Work on exploring the Far-Eastern history during the years of the Revolution and Civil War is going on at the present time [1, 24, 25, 49, 50]. It should be noted, that the main bulk of scientific works is devoted to the problems of the Far East mainland part (Primorsky krai, Khabarovsk krai, Amurskaya oblast and others), though the history of the Revolution and Civil War in Kamchatka is still waiting for its investigators.

The changed methodological approaches to the interpretation of the historical events of the early XX century require new work on the selection and publication of documents, presentation of them to a wide range of researchers and readers. Historians should not limit themselves within the scope of only one type of sources. There is an urgent need to turn to cinematographic and photographic documents which depictured the events. Therefore, in these conditions, we should focus on the study of the funds of regional archives and museums, publication of full-fledged collections of documents, monographies of the source-study character. New approaches to the interpretation of the source base of historical investigations are reflected in the collective monography "Kamchatka in the period of revolutions of 1917, the Civil War and the first soviet reforms: a source-study aspect," which was prepared and edited by the historians of Kamchatka [29].

\section{Conclusion}

Historical sources, non-homogeneous in their content, structure and integrity, created by various people in the process of conscious purposeful activity and used by them for achieving definite goals are of great importance for the modern researchers. The documents 
preserved by the employees of the State Archives of Khabarovsk, Kamchatka, and Primorsky krais will undoubtedly enable historians to reconstruct the unique events of the Revolution and Civil War in Kamchatka, their atmosphere, their content and meaning. However, the information must be not only extracted, but also to be assessed critically and interpreted. Studying fragments of the past reality researchers will have to draw logical conclusions about the meaning of the very fact of this or that source presence and to be able to reproduce on their basis a consistent image of the events of 1917-1922 in Kamchatka, the testimony of which these sources provide.

\section{References}

1. N. A. Butenin, Humanitarian Researches in Eastern Siberia and the Far East, 3, 19 (2012)

2. Kamchatka Krai State Archive, Regional'noye upravleniye Federal'noy sluzhby bezopasnosti Rossii po Kamchatskomu kraiu (Archival Fund P-1199)

3. Kamchatka Krai State Archive, Petropavlovskaya gorodskaya Duma, g. Petropavlovsk-na-Kamchatke (1917-1922 gg.), (Archival Fund R-8)

4. Kamchatka Krai State Archive, Kamchatsky oblastnoy komitet Soveta rabochikh $i$ krest'yanskikh deputatov (1917-1918 gg.), (Archival Fund R-10)

5. Kamchatka Krai State Archive, Tretiy Kamchatskiy oblastnoy syezd predstaviteley naseleniya, g. Petropavlovsk-na-Kamchatke (1920 g.), (Archival Fund R-80)

6. Kamchatka Krai State Archive, Sovet Palanskogo sel'skogo obshchestva (Archival Fund R-86)

7. Kamchatka Krai State Archive, Palanskoye volostnoye pravleniye Petropavlovskogo uyezda Kamchatskoy oblasti, (Archival Fund R-99)

8. Kamchatka Krai State Archive, Ust'-Kamchatskiy volispolkom Petropavlovskogo uyezda, (Archival Fund R-126)

9. Kamchatka Krai State Archive, Kamchatskiy oblastnoy ispolnitel'nyi komitet (oblispolkom) Vremennogo Sibirskogo avtonomnogo pravitel'stva, g. Petropavlovskna-Kamchatke (1917-1919 gg.), (Archival Fund R-130)

10. Kamchatka Krai State Archive, Nizhnekamchatskiy volispolcom Petropavlovskogo uyezda, (Archival Fund R-201)

11. Kamchatka Krai State Archive, Zavoykinskoye volostnoye upravleniye Petropavlovskogo uyezda, (Archival Fund R-203)

12. Kamchatka Krai State Archive, Zavoykinskiy volispolkom Petropavlovskogo uyezda (Archival Fund R-224)

13. Kamchatka Krai State Archive, Kamchatskiy oblastnoy komissar Vremennogo pravitel'stva» (1917 g.) (Archival Fund R-234)

14. Kamchatka Krai State Archive, Krestovskiy sel'kom Kluchevskoy volosti Petropavlovskogo uyezda, (Archival Fund R-240)

15. Kamchatka Krai State Archive, Drankinskiy volispolkom Petropavlovskogo uyezda, (Archival Fund R-249)

16. Kamchatka Krai State Archive, Larin Ivan Yemel'yanovich - pervyi predsedatel' Petropavlovskogo gorodskogo i Kamchatskogo oblastnogo Sovetov krest'yanskikh, rabochikh i soldatskikh deputatov, chlen Kamchatskogo gubrevkoma (Archival Fund $\mathrm{R}-497)$ 
17. Khabarovsk Krai State Archive, Otdel Dal'nevostochnoy krayevoy komissii po sobraniyu i izucheniyu materialov po istorii Oktyabr'skoy revolutsii i istorii VKP(b) pri Khabarovskom krayevom komitete VKP(b) (Archival Fund P-44)

18. Khabarovsk Krai State Archive, «Partarkhiv Khabarovskogo kraykoma KP RSFSR» [Party archive of Khabarovsk krai committee of the CP RSFSR]

19. Khabarovsk Krai State Archive, Dal'nevostochnoye otdeleniye Vsesoyuznogo obshchestva starykh bolshevikov, g. Khabarovsk (Archival Fund P-442)

20. Khabarovsk Krai State Archive, Upravleniye po delam arkhivov administratsii Khabarovskogo kraya (Archival Fund R-39)

21. Khabarovsk Krai State Archive, Krayevaya Dal'nevostochnaya partizanskaya komissiya (Archival Fund R-181)

22. Khabarovsk Krai State Archive, Rayonnaya Bikinskaya partizanskaya komissiya (Archival Fund R-663)

23. Khabarovsk Krai State Archive, Leninskaya raionnaya partizanskaya komissiya (Archival Fund R-1277)

24. Proceedings of the international scientific conference "The Civil War in the Russian Far East: Results and Conclusions" (Vladivostok, 1992)

25. The Russian Far East in the period of revolutions of 1917 and the Civil War: The History of the Russian Far East V. 3. (Dalnauka, Vladivostok, 2003)

26. For the power of the Soviets in Kamchatka: a collection of articles (Kamchatskaya Pravda, Petropavlovsk-Kamchatsky 1957)

27. B. I. Mukhachev, For the power of the Soviets: documents and materials (Far-Eastern Publishing House, 1967)

28. B. I. Mukhachev 1967. For the power of Soviets, 1920-1922: documents and materials: a collection of works devoted to the 50th anniversary of the Great October Socialist Revolution (Party Archive of the Kamchatka Regional Committee of the CPSU, Far-Eastern Publishing House, 1967)

29. Kamchatskiy listok (1917)

30. V. A. Ilyina, Kamchatka in the period of revolutions of 1917, the Civil War, and the first soviet reforms: a source-study aspect (Publishing House of the Vitus Bering Kamchatka State University, Petropavlovsk-Kamchatsky, 2017)

31. A. I. Krushanov, Struggle for the power of the Soviets in the Far East and Zabaykalye (March 1917 - March 1920), (Vladivostok, 1962)

32. A. I. Krushanov, October in the Far East, (Vladivostok, 1968)

33. A. I. Krushanov, The victory of the Soviet power in the Far East and Zabaykalye (1917 - April 1918), (Vladivostok, 1983)

34. S. V. Zakharov, Chronicle of the RSFSR North-East peoples' life, 1917-1985: a collection of documents (Far-Eastern Publishing House, Petropavlovsk-Kamchatsky, 1968)

35. B. I. Mukhachev, Strugglers for the power of the Soviets in Kamchatka, (Far-Eastern Publishing House, Petropavlovsk-Kamchatsky, 1977)

36. B. I. Mukhachev, The establishment of the Soviet power and struggle with foreign expansion in the North-East of the USSR (1917-1920) (Nauka, Novosibirsk, 1975)

37. B. I. Mukhachev, Ye. M. Ilyenko, I. A. Yarovikova, The first Sovdep: documents and materials concerning the Petropavlovsk Council of workers' and soldiers' deputies: a collection of works (Far-Eastern Publishing House, Petropavlovsk-Kamchatsky, 1967) 
38. B. I. Mukhachev, Petropavlovsk-Kamchatskiy, 1740-1990: the history of the city in documents and memoirs (Administration of Petropavlovsk-Kamchatsky, Petropavlovsk-Kamchatsky, 1994)

39. G. I. Serykh, A. S. Sesitskaya, N. I. Syao-Kon-min, Kamchatka Krai State Archives funds guide (Petropavlovsk-Kamchatsky, 2014)

40. Russian State Historical Archive of the Far East, Kantselyariya gubernatora Kamchatskoy oblasti, g. Petropavlovsk-Kamchatsky (1906-1922 gg.) (Archival Fund 1005)

41. Russian State Historical Archive of the Far East, Kamchatskiy oblastnoy komitet Vremennogo Rossiyskogo pravitel'stva (Kolchaka), g. Petropavlovsk-Kamchatsky, 1916-1921 gg. (Archival Fund R-1378)

42. Russian State Historical Archive of the Far East, Upravlyayushchiy Kamchatskoy oblast'yu Vremennogo Rossiyskogo pravitel'stva, g. Petropavlovsk-Kamchatsky» (1917-1929 gg.) (Archival Fund R-1380)

43. Russian State Historical Archive of the Far East, Kamchatskiy gubernskiy narodnorevolutsionnyi komitet, g. Petropavlovsk-Kamchatsky (1911-1922 gg.) (Archival Fund $\mathrm{R}-1382$ )

44. Russian State Historical Archive of the Far East, Kamchatskiy vremennyi voyennorevolutsionnyi komitet. g. Petropavlovsk-Kamchatsky. 1919-1920 (Archival Fund R1383)

45. Russian State Historical Archive of the Far East, Kamchatskaya oblastnaya izbiratel'naya komissiya po vyboram v Uchreditel'noye sobraniye Dal'nego Vostoka, g. Petropavlovsk-Kamchatsky (1920 g.) (Archival Fund R-1387)

46. Russian State Historical Archive of the Far East, Kantselyariya osobo upolnomochennogo Vremennogo Priamurskogo Pravitel'stva v OkhotskoKamchatskom kraie, g.Petropavlovsk-Kamcatsky (1921-1922 gg.) (Archival Fund R1403)

47. Russian State Archive of the Far East, The list of archival funds (http://rgiadv.ru/fonds/spisok-fondov)

48. S. V. Slivko, The activity of Dalistpart on studying the history of revolutionary movement, Civi War and intervention in the Far East (1922-1939) (Irkutsk State University, Irkutsk, 2015)

49. V. V. Sonin, Great October and the development of the Soviet state-building in the Far East (1917-1922) (Vladivostok, 1987)

50. O. P. Fedirko, Bulletin of Buryat State University, 7 (2010)

51. I. V. Shvets, The Civil War in Siberia and the Far East of Russia: the struggle of republican and monarchical tendencies (1917-1922) (Komsomolsk-on-Amur, 2007) 